Department of Economics- FEA/USP

\title{
Multi-Sectorial Convergence in Greenhouse Gas Emissions
}

GUILHERME DE OLIVEIRA

DEISE BOURSCHEIDT

WORKING PAPER SERIES № 2015-34 


\title{
DEPARTMENT OF ECONOMICS, FEA-USP \\ WORKING PAPER № 2015-34
}

\section{Multi-Sectorial Convergence in Greenhouse Gas Emissions}

\author{
Guilherme de Oliveira (guilherme.decon@usp.br) \\ Deise Bourscheidt (deise.bourscheidt@uffs.edu.br)
}

\begin{abstract}
This paper uses a multi-sectorial dynamic panel to test the hypothesis of per capita convergence in greenhouses gas emissions. This has been made possible through the recent publication of the World Input Output Database. The empirical strategy applies conventional estimators of random and fixed effects, and Arellano and Bond's (1991) GMM to the main pollutants related to the greenhouse effect. We found robust evidence of convergence in $\mathrm{CH} 4$ emissions in sectors linked to agriculture, food industry and services. Regarding CO2 emissions, we found moderate evidence in agriculture and food industry, manufacturing of non-durable goods and services. In all cases, the time for convergence was less than fifteen years. In the emissions for energy use, the largest source of global warming, we found moderate evidence only in the extractive industry sector. All other pollutants presented weak or lack of evidence.
\end{abstract}

Keywords: Greenhouse gas emissions; multi-sectorial convergence; panel data.

JEL Codes: Q5; Q52; C33.

\section{Convergência Multi-Setorial na Emissão de Gases do Efeito Estufa}

Resumo: Este artigo usa um painel dinâmico multi-setorial para testar a hipótese de convergência per capita na emissão de gases do efeito-estufa. Tal teste tornou-se possível com a recente publicação da World Input Output Database. A estratégia empírica aplica estimadores convencionais de efeitos aleatórios e fixos, e também um GMM de Arellano e Bond (1991), para os principais poluentes relacionados ao efeito estufa. Encontramos evidências robustas de convergência na emissão de $\mathrm{CH} 4$ em setores ligados à agricultura, indústria de alimentos, e serviços. Com relação à emissão de $\mathrm{CO} 2$, encontramos evidencias moderadas na agricultura, indústria de alimentos, indústria de bens-duráveis e serviços. Em todos os casos, o tempo para convergência foi menor do que quinze anos. Nas emissões relevantes pelo uso de energia, uma das maiores fontes causadoras do efeito estufa, encontramos evidências moderadas apenas na indústria extrativa. Todos os demais poluentes apresentaram evidência fraca ou ausência de evidências.

Palavras-Chave: Gases do efeito-estufa; Convergência multi-setorial; dados em painel. 


\title{
Multi-Sectorial Convergence in Greenhouse Gas Emissions
}

\author{
Guilherme de Oliveira \\ Department of Economics, University of São Paulo, Brazil. \\ E-mail: guilherme.decon@usp.br \\ $\&$ \\ Deise Bourscheidt \\ Colegiado de Ciências Econômicas, Federal University of Fronteira Sul, Brazil. \\ E-mail: deise.bourscheidt@uffs.edu.br
}

\begin{abstract}
Resumo: Este artigo usa um painel dinâmico multi-setorial para testar a hipótese de convergência per capita na emissão de gases do efeito-estufa. Tal teste tornou-se possível com a recente publicação da World Input Output Database. A estratégia empírica aplica estimadores convencionais de efeitos aleatórios e fixos, e também um GMM de Arellano e Bond (1991), para os principais poluentes relacionados ao efeito estufa. Encontramos evidências robustas de convergência na emissão de $\mathrm{CH} 4$ em setores ligados à agricultura, indústria de alimentos, e serviços. Com relação à emissão de $\mathrm{CO} 2$, encontramos evidencias moderadas na agricultura, indústria de alimentos, indústria de bens-duráveis e serviços. Em todos os casos, o tempo para convergência foi menor do que quinze anos. Nas emissões relevantes pelo uso de energia, uma das maiores fontes causadoras do efeito estufa, encontramos evidências moderadas apenas na indústria extrativa. Todos os demais poluentes apresentaram evidência fraca ou ausência de evidências.
\end{abstract}

Palavras-chave: Gases do efeito-estufa; Convergência multi-setorial; dados em painel.

\begin{abstract}
This paper uses a multi-sectorial dynamic panel to test the hypothesis of per capita convergence in greenhouses gas emissions. This has been made possible through the recent publication of the World Input Output Database. The empirical strategy applies conventional estimators of random and fixed effects, and Arellano and Bond's (1991) GMM to the main pollutants related to the greenhouse effect. We found robust evidence of convergence in $\mathrm{CH} 4$ emissions in sectors linked to agriculture, food industry and services. Regarding CO2 emissions, we found moderate evidence in agriculture and food industry, manufacturing of non-durable goods and services. In all cases, the time for convergence was less than fifteen years. In the emissions for energy use, the largest source of global warming, we found moderate evidence only in the extractive industry sector. All other pollutants presented weak or lack of evidence.
\end{abstract}

Keywords: Greenhouse gas emissions; multi-sectorial convergence; panel data.

JEL: Q5; Q52; C33. 


\section{Introduction}

The relationship between economic growth and the environment has received renewed attention in the environmental literature. Some of the main empirical controversies in the topic are related to the Environmental Kuznets Curve (EKC) - which suppose an $U$-shaped relation between per capita emissions and income -, and the convergence hypothesis in greenhouse gases (GHG) emissions - which aims to verify whether countries are converging to a steady-state of emissions. This paper is related to the latter issue.

The pioneering work on this topic is credited to Strazicich and List (2003), who use an ordinary least squares (OLS) estimator and unit root tests for panel data, for a sample of OECD countries. Evidence in favor of the convergence hypothesis was found. From that work, a similar controversy in the empirical literature on economic growth can currently be observed in the environmental literature: papers such as Romero-Avila (2008) Westerlund and Basher (2007) and others found significant evidence in favor of convergence. However, Aldy (2006) and Criado and Grether (2011), among others, do not support such a hypothesis.

One of the sources of divergence in the results is the sample size: as it increases, the evidence of convergence decreases. Another is the technique used: OLS and unit root tests for panel data tend to confirm it. However, more elaborate techniques, such as Markov chains and other dynamic analysis do not. Another point is related to the concentration of studies examining only a cross-country dimension of $\mathrm{CO} 2$ emissions, while other relevant perspectives are left out, such as the analysis of sectorial convergence, and other sources of GHG emissions. This can partially be explained by the scarcity of multi-sectorial databases to enable a comprehensive and consistent estimation of the hypothesis across countries and sectors.

Such a situation changes with the availability of some new databases such as the World International Input-Output Database (WIOD) (Timmer et al., 2015), which estimates inter-sectorial data for intermediate consumption, value added, employment, investment, depreciation and capital stock, used for economic impact analysis via input-output matrixes. WIOD also has social and environmental annexes. The latter collects sectorial environmental data, including emissions of the main GHG. It provides enough variation to estimate convergence between sectors in the main world economies.

A multi-sectorial test for the convergence hypothesis in GHG emissions is particularly relevant to check whether there is heterogeneity between sectorial samples, e.g. are the durable goods industrial sectors converging? And if they are, are they doing so faster than the agricultural and food sectors? Furthermore, many models of computable general equilibrium, for instance, 
assume a certain degree of convergence between countries and sectors to estimate trend scenarios for climate change. If however, per capita emissions are not converging, these models can be seriously incorrect, generating bad policy recommendations.

This paper contributes to the environmental economics literature by estimating a dynamic multi-sectorial panel data that that sheds some light on the debate of convergence hypothesis in per capita GHG emissions (not only CO2). For this purpose, a theoretical convergence function is derived based on a joint production mechanism, and then, a model is estimated using a panel of 33 sectors of WIOD, which are available for a set of 39 countries between 1996 and 2007.

The rest of this paper is organized as follows: Section 2 briefly outlines the literature. Section 3 presents the identification strategy, while Section 4 presents the sample and the data source. Section 5 discusses the main results and finally some conclusions are presented.

\section{Related literature}

The empirical literature on the convergence hypothesis in GHG emissions is recent, dating back to the early 2000s, and it focuses mainly on CO2 emissions. Regarding econometric techniques, the literature is less-autonomous as it is influenced by past developments in the theory of economic growth. This is not by chance since emissions and income are strongly correlated in time.

Strazicich and List (2003) conducted the first empirical test in which cross-section and time series models were estimated using data of CO2 emission for 21 industrialized countries from 1960 to 1997. The authors found significant evidence that CO2 emissions converged, although they did not set their speed or time. Aldy (2006) focused on expanding the sample of the pioneers for 88 countries from 1960 to 2000. The author found no evidence of convergence for this sample, only for a subset of OECD countries. Furthermore, forecasts based on a Markov transition matrix provided weak evidence of future convergence for the global sample, indicating that emissions could be diverging in the short-run.

Westerlund and Basher (2007) increased the period studied from 1870 to 2002, using similar econometric techniques and sample sets. They found support for empirical convergence, both in absolute and conditional terms. Their main contribution was to estimate the convergence rate which increased after the 1970s. In turn, Romero-Avila (2007) examined the existence of stochastic and deterministic convergence in $\mathrm{CO} 2$ emissions for 23 countries using unit root tests for panel data. Overall, the analysis supported strong stochastic and deterministic convergence in emissions. 
Pen and Sévi (2010) analyzed the energy intensity convergence for 97 countries between 1971 and 2003 using the criteria for stochastic convergence proposed by Pesaran (2007). Unit root tests rejected the hypothesis of global convergence. For the Midwest OECD's members, and for subsets of European countries, the non-convergence is "less strongly rejected". The control for structural breaks in the time series offers marginal gains in favor of convergence.

Karanfil and Tykhonenko (2010) used a Bayesian estimator for the analysis of convergence of CO2 emissions for a sample of 22 European countries between 1971 and 2006. First, they found that the hypothesis of absolute convergence is supported, and a slight upward convergence is observed. Secondly, the fact that the countries differ considerably in their convergence speed and volatility makes it possible to identify groups of countries with common features.

Another work that sought to analyze the hypothesis was carried out by Herrerias (2012), using a distributive dynamic approach. The sample set was limited to 25 European Union (EU) countries between 1920-2007. It examined whether the convergence patterns may differ if weighted by the population and economic indicators of each country (unobservable effects are not controlled). The unweight analysis indicated that the convergence patterns differ among countries before and after the Second World War, tending to further convergence after the 1970s. Weighting results shown that the convergence is much faster when these characteristics are explicitly considered, and thus, convergence may be conditional.

Li and Lin (2013) evaluated the global convergence of per capita CO2 emissions between 1971-2008. They observed absolute convergence within subsamples classified according to income level. However, a global sample containing 110 countries provided weak evidence of absolute convergence. In addition, the empirical strategy uses per capita income to control for conditional convergence. In this case, the relationship between an increase in income and $\mathrm{CO} 2$ emission is different. In particular, per capita emissions in developed countries remain at steady state as income increases. Hence, its main result contradicts EKC.

Camarero, Picazo-Tadeo and Tamarit (2013) tested the convergence in the intensity of CO2 emissions (CO2 emissions relative to GDP) across OECD countries between 1960-2008, based on determinants of energy intensity (energy consumption/GDP), and a carbonization index (CO2 emissions/energy consumption). Estimating convergence clubs, they shown that differences in convergence of $\mathrm{CO} 2$ emission are determined mostly by differences in the convergence of the carbonization index, and not by differences in convergence in energy intensity.

This brief literature review shows divergent results. In general, simple models of crosssection and unit root tests for panel data found significant convergence evidence, while different 
statistical techniques, such as Markov chains, for instance, do not support convergence. Another issue is the sample size: large samples do not report convergence evidence, which is found only in small groups of homogeneous countries, such as the OECD members. When heterogeneous characteristics between countries are considered, the rate of convergence loses strength.

This work examines three of the aspects mentioned in the literature. Firstly, the sample size is expanded to 33 sectors among 39 countries, during 11 years of observations. Secondly, as well as $\mathrm{CO} 2$, other GHG are explicitly modeled, and finally a dynamic panel estimator circumvents inconsistency problems of estimation based on conventional methods.

\section{The identification strategy}

This section describes the identification strategy, an approach based on Islam (1995). A joint production mechanism is supposed, in which the use of labor and capital in a production function generates two outputs: one good (economic growth) and one bad (GHG emissions). Therefore,

$$
Y_{i j}=K_{i j}^{\alpha}\left(A_{i j} L_{i j}\right)^{1-\alpha} \rightarrow E_{i j}
$$

in which $Y$ is the output, $K$ is the capital stock, $A$ is the technological level, $L$ is the number of workers and $E$ is the bad output, $i$ and $j$ describe sectors and countries, respectively. In fact, the logic is similar to the green Solow model set out in Brock and Taylor (2010). However, given the difficulty of obtaining data on abatement investment, the Green Solow model is not taken into account for the present theoretical derivation, but as the reader may notice, the empirical equation is equivalent.

Therefore, due to the strong empirical correlation between income and emissions, the generating process of GHG emissions can be assumed to be the same as the one that generates income for the economy, $E_{i j}=K_{i j}{ }^{\alpha}\left(A_{i j} L_{i j}\right)^{1-\alpha}$.

As in the canonical Solow model, it is supposed that the population and technology growth rates are exogenously given by $L_{i j_{t}}=L_{i j}(0) e^{n_{i j} t}$ and $A_{i j_{t}}=A_{i j}(0) e^{g_{i j} t}$, respectively. Since a fraction $s$ of the sectorial income is saved and automatically reverted into investment, and emissions and capital per effective worker are defined as $e_{i j}=E_{i j} / A_{i j} L_{i j}$ e $k_{i j}=K_{i j} / A_{i j} L_{i j}$, respectively, the capital-labor ratio changes over time according to: 


$$
\frac{d k_{i j}}{d t}=s_{i j} k_{i j}^{\alpha}-\left(n_{i j}+g_{i j}+\delta_{i j}\right) k_{i j}
$$

Solving (2) for the capital stock per effective worker, the value of capital stock per worker in steady-state is obtained:

$$
k_{i j}^{*}=\left[\frac{s_{i j}}{\left(n_{i j}+g_{i j}+\delta_{i j}\right)}\right]^{1 /(1-\alpha)} .
$$

In steady-state, capital stock growth is determined by the population growth rate, savings rate, technical progress and an exogenous parameter of depreciation $\delta$. Substituting the balanced capital stock on the emissions by effective worker, per capita emission in steady state is obtained (which is determined by the same parameters as in Eq. (3)). Applying the logarithm to the expression of per capita emissions, Eq. (4) is reached, a linear expression for the emissions in balance. Hence,

$$
\ln \left[\frac{E_{i j}}{L_{i j}}\right]=\ln A_{i j_{0}}+g_{i j} t+\frac{\alpha}{1-\alpha} \ln \left(s_{i j}\right)-\frac{\alpha}{1-\alpha} \ln \left(n_{i j}+g_{i j}+\delta_{i j}\right)
$$

Now the emissions are normalized by the number of workers, and not by the number of effective workers; thus, the technological level, $A$, is on the right hand of equation. If the intention were to estimate Eq. (4) for analyzing the sensibility of per capita emissions for a group of countries at some moment in time with OLS, it is possible to assume that $\ln A_{i j_{0}}=a+\mu$, a constant plus stochastic perturbation. The following model would be estimated:

$$
\ln \left[\frac{E_{i j}}{L_{i j}}\right]=a+\frac{\alpha}{1-\alpha} \ln \left(s_{i j}\right)-\frac{\alpha}{1-\alpha} \ln \left(n_{i j}+g_{i j}+\delta_{i j}\right)+\mu_{i j}
$$

Using OLS, the linear adjustment in Eq. (5) is inconsistent, since the variables in the error term that explains emissions and which are correlated with the savings and population growth rates affect the consistency of the parameters defined as $\frac{\alpha}{1-\alpha}$. The basic conjecture in this article is about modeling emissions per capita, considering that " $a$ " can be estimated for each country, the fixed effect, and that $g t$ by a set of time dummies in panel data. 
Thus, the equation of per capita convergence, adapted from Mankiw, Romer and Weil (1992), is derived assuming that $\epsilon_{i j} *$ is the per capita emissions in steady-state and $\epsilon_{i j}$ the current emissions in $t$. Approaching the steady-state, the equation for convergence in time is given by:

$$
\frac{d \ln \epsilon_{i j_{t}}}{d t}=\varphi\left[\ln \epsilon_{i j}^{*}-\ln \epsilon_{i j}\right]
$$

in which $\varphi=\left(n_{i j}+g_{i j}+\delta_{i j}\right)(1-\alpha)$. Integrating Eq. (6), it follows that:

$$
\ln \epsilon_{i j}=\left(1-e^{-\varphi \tau}\right) \ln \epsilon_{i j}^{*}+e^{-\varphi \tau} \ln \epsilon_{i j}{ }_{t 1}
$$

in which $\epsilon_{i j}$ is the emissions at the initial time and $\tau=(t 2-t 1)$. Deducting the initial per capita emissions from the both sides of Eq. (7) and rearranging, it follows that:

$$
\ln \epsilon_{i j_{t 2}}-\ln \epsilon_{i j_{t 1}}=\left(1-e^{-\varphi \tau}\right)\left(\ln \epsilon_{i j}{ }^{*}-\ln \epsilon_{i j}\right) .
$$

Deducting $\epsilon_{i j}{ }^{*}$, inserting the technological parameter to the right-hand side, and collecting $\epsilon_{i j}$, it follows that:

$$
\begin{aligned}
& \ln \epsilon_{i j}=\left(1-e^{-\varphi \tau}\right) \frac{\alpha}{1-\alpha} \ln \left(s_{i j}\right)-\left(1-e^{-\varphi \tau}\right) \frac{\alpha}{1-\alpha} \ln \left(n_{i j}+g_{i j}+\delta_{i j}\right)+e^{-\varphi \tau} \ln \epsilon_{i j}+ \\
& \left(1-e^{-\varphi \tau}\right) \ln A_{0}+g\left(t 2-e^{-\varphi \tau} t 1\right) .
\end{aligned}
$$

Eq. (9) is the main equation in this paper because it covers the equation of conditional convergence that will be modeled by a dynamic panel. When modeling in Eq. (9) $\left(1-e^{-\varphi \tau}\right) \ln A_{0}$, technology, as a fixed effect in time, and $g\left(t 2-e^{-\varphi \tau} t 1\right)$ - technical progress, as a set of dummy variables of time, a dynamic panel can be defined according to:

$$
y_{i j_{t}}=\gamma y_{i j_{t-1}}+\sum_{l=1}^{2} \beta_{k} x_{i j_{t}}^{k}+\pi_{t}+\theta_{i}+\vartheta_{i j_{t}}
$$

in which:

$y_{i j_{t}}=\ln \epsilon_{i j_{t 2}}:$ logarithm of GHG emissions per worker in $t_{2}$, in sector $i$ of country $j$; 
$y_{i j_{t-1}}=\ln \epsilon_{i j_{t 1}}$ : logarithm of GHG emissions per worker in the initial time, in sector $i$ of country $j$; $\gamma=e^{-\varphi \tau}$ : parameter used for estimating the convergence rate; it measures the impact that the initial emission has on the current multi-sectorial level;

$\beta_{1}=\left(1-e^{-\varphi \tau}\right) \frac{\alpha}{1-\alpha}:$ elasticity of the savings rate on the emissions;

$\beta_{2}=\left(1-e^{-\varphi \tau}\right) \frac{\alpha}{1-\alpha}:$ elasticity of population growth, technology and depreciation rate;

$x_{i j_{t}}^{1}=\ln \left(s_{i j}\right):$ logarithm of the savings rate;

$x_{i j_{t}}^{2}=\ln \left(n_{i j}+g_{i j}+\delta_{i j}\right):$ logarithm of the population growth rate, technology and depreciation;

$\pi_{t}=g\left(t 2-e^{-\varphi \tau} t 1\right)$ : effect of technical progress at the time, modeled with a set of temporal dummies;

$\theta_{i}=\left(1-e^{-\varphi \tau}\right) \ln A_{0}:$ sectorial fixed effect;

$\vartheta_{i j_{t}}$ : idiosyncratic perturbation term that varies among sectors, countries and time.

A dynamic panel estimation enables the control of the results of conditional convergence in the emissions of GHG by observable and unobservable effects specific for each sector in each country in the sample composed of 39 countries in the 1996-2007 period.

\subsection{A panel data approach}

The main issue here in Eq. (10) is how to model specific effects of each sector in each country. Three techniques were used: the first considers the sector-specific effects as random (GLS$\mathrm{RE}$ ), while the others considers these effects as fixed. Finally, and given the possible endogeneity of a lagged dependent variable, a GMM is used. The first estimator supposes, by construction, which the random effect is uncorrelated with other explanatory variables in the model (10). The second approach estimates fixed effects (FE) via dummies, as in Islam (1995), a specific-sector effect, allowing its correlation with other explanatory variables. The third estimator uses the lag-dependent variable as instruments to control a possible endogenous effect.

The identification hypothesis from the FE model is: the absence of a serial correlation between the idiosyncratic error and the explanatory variables plus the fixed effect, that is, strict exogeneity, $F E 1: E\left[\vartheta_{i t} \mid x_{i j}, \theta_{i}\right]=0$; Full rank, that is, the variables vector $x$ must have an inverse $F E 2: \operatorname{rank} E\left[x_{i j}{ }^{\prime} x_{i j}\right]=k$; Finally, homoscedasticity between individuals in cross-sections is 
assumed; however, this hypothesis is related to the correlation among the error terms in time, $F E 1: E\left[\vartheta_{i t} \vartheta_{i t}{ }^{\prime} \mid x_{i j}, \theta_{i}\right]=\sigma^{2} \vartheta I_{t}$.

It is expected that the estimated convergence rate, using the model of effects at random, is underestimated as the intrinsic country effects are correlated with the explanatory variables. Considering the model of FE, the rate must change considerably because the characteristics are explicitly modeled. In general, details from both estimates are very well known and may be verified in Greene (2000) and Wooldridge (2002).

In this context, the estimates are not based on Hausman's test because this research does not identify these ad hoc from the right model, rather from an empirical history about a convergence hypothesis on per capita carbon dioxide emissions. In addition, in this paper Hausman's test is not essential because each model is estimated for comparative purposes.

As Eq. (10) has a lagged dependent variable, fixed and random effects estimates can be inconsistent given the violation of the hypothesis of strict exogeneity, arising from the correlation between the residue and the lagged dependent variable. If the time is long enough, the fixed effects via a dummy would not report a biased estimation, but this estimate is performed for 12 years, from 1996 to 2007, and thus may be influenced by some endogeneity. To account for this, a GMM estimator from Arellano and Bond (1991) is used.

As the lagged variable is a central point in the identification strategy, two time intervals are adopted. According to the literature, first one lagged year is used. However, it is possible that one year is too short a period to evaluate convergence, so four years are used.

\subsection{Sample}

The data used in this article were collected in WIOD (2015) - Timmer et al. (2015), a recent database, which as well as enabling new economic analysis via input-output models, also brings together a set of information for multi-sectorial econometric analysis. In this work, we use two WIOD's annexes. The first has socioeconomic information on the number of workers, capital stock and depreciation rate for the 39 sectors of 40 countries listed in this dataset.

WIOD has data available for the 27 EU-economies, and the 13 largest economies around the world, covering all Continents around the globe. Nevertheless, the base still has some incomplete data, which have resulted in the exclusion of some cross-section units: as is the case of intersectorial employment in China, excluded from the sample. Moreover, we decided not to use the "Rest of the World" as a unit of analysis. 
To compute the savings rate in (10), it is supposed that all savings are automatically transformed into investment. In this case, we estimate the savings rate isolating investment, $I$, in (11), and normalizing by income:

$$
K_{i j_{t}}=\left(1-\delta_{i j}\right) K_{i j_{t-1}}+I_{i j_{t}}
$$

Depreciation rates are different for each of the 39 sectors and were considered when calculating the savings rate following the description in Timmer et al. (2015). Regarding population growth rate, $n$, we used a proxy variable defined by the growth rate of the labor force. Moreover, a rate of technical progress was used, $g, 4 \%$ (standard in the empirical literature). Thus, we have $\left(n_{i j}+g_{i j}+\delta_{i j}\right)$ in $(10)$.

All inventory data and capital investment are at 1995 prices, deflated according to Timmer et al. (2015). This approach has two drawbacks: $2.1 \%$ of the observations for the savings rate varied negatively in the period, i.e. there was disinvestment. To estimate (10) we must linearize (3), and thus, we consider divestment as zero savings; nevertheless, we use employment data to compute $n$. Thus, $5.32 \%$ of the observations had a negative change in $\left(n_{i j}+g_{i j}+\delta_{i j}\right)$, given the high unemployment rate from one year to another in countries such as Latvia. In these cases, the observations were excluded.

The second annex includes environmental information, the GHG emissions in tons per sector over 1995 and 2007. To represent them, we selected the following gases: methane emissions CH4; carbon monoxide CO; CO2 emissions by sector; and the emissions relevant energy use, which represent some of the gases most responsible for climate change (IPCC, 2014).

Once again, we faced problems with data limitation as some sectors had no information record and were excluded. In total, beside the full sectorial WIOD sample (14,553 observations in the series of emission relevant energy use; 15,432 in CO2 emissions; 15,443 in CH4; 15,048 in $\mathrm{CO}$ ), which are already aggregates for cross country comparison, we aggregate the WIOD sectors in the following samples:

Sample-A - [1] Agriculture, Hunting, Forestry and Fishing + [2] Food, Beverages and Tobacco 948 observations (emissions for energy use), 924 (CO2 and $\mathrm{CH} 4), 912$ (CO);

Sample-B - [6] Mining and Quarrying + [7] Wood and Cork + [8] Coke, refined petroleum and nuclear fuel $+[9]$ Chemicals $+[10]$ Rubber and plastics $+[11]$ Other non-metallic mineral -2.808 (emissions for energy use), $2.784(\mathrm{CO} 2), 2.776(\mathrm{CH} 4), 2.712(\mathrm{CO})$; 
Sample-C - [3] Textiles and textile + [4] Leather, and footwear + [5] Pulp, paper, printing and publishing - 1.404 (emissions for energy use), 1.356 (CO2 and $\mathrm{CO}), 1.352$ (CH4);

Sample-D - [12] Basic metals and fabricated metal + [13] Machinery + [14] Electrical and optical equipment $+[15]$ Transport equipment + [16] Manufacturing nec, recycling + [16] Electricity, gas and water supply + [17] Construction - 3.288 (emissions for energy use), 3.240 (CO2), 3.232 (CH4), 3.216 (CO);

Sample-E - [18] Sale, maintenance and repair of motor vehicles and motorcycles; retail sale of fuel + [19] Wholesale trade and commission trade + [20] Retail trade, except of motor vehicles and motorcycles; repair of household goods + [21] Hotels and restaurants + [22] Inland transport + [23] Water transport + [24] Air transport + [25] Other supporting and auxiliary transport activities; activities of travel agencies; [26] Post and Telecommunications + [27] Financial intermediation + [28] Real estate activities + [29] Renting and other business activities + [30] Public administration + [31] Education + [32] Health and social work + [33] Other personal services + [34] Domestic services - 7,476 (emissions for energy use), 7.176 (CO2), 7.188 (CH4), 6.900 (CO).

Therefore, Sample-A consists of sectors related to production and industrialization of food; Sample$\mathrm{B}$ is the extractive industry; Sample-C is the non-durable goods industry; Sample-D consists of sectors of durable goods; and Sample-E are all services. Finally, 144 regressions for these 6 sample sets were done and the main results are presented below.

\section{Results}

Table 1 shows the estimated parameters of RE, FE, and GMM for the whole sample. First, considering one lag, both models correctly predict the signs of parameters associated with the savings rate, population, depreciation and technical progress growth rates. The statistical significance in most of them also suggests that they are important in explaining emissions variations. Note, however, that they fail to be statistically identical, as required by the canonical Solow model ${ }^{1}$.

Regarding convergence, the GLS estimator of RE reports low rates resulting in a long timehorizon for convergence in both pollutants. Note that the use of FE and GMM increased the rate of convergence in all gases, making it statistically equivalent in number of years. Both returned a time of 4-6 years for convergence in the emissions of $\mathrm{CO} 2$, about 5-3 in $\mathrm{CH} 4$, and approximately 2-3 years for CO. Regarding emissions relevant energy use, the largest source of GHG, the convergence

\footnotetext{
1 The entire sample set was estimated restricting the parameters of the savings and population growth rates to be statistically identical, as the Solow model predicts. However, the results in terms of convergence were similar, and are not presented.
} 
rate was significant only in models of random and fixed effects. From the GMM estimate, there is no evidence of convergence in the whole sample.

Table 1 - Results for the whole sample 1996 - 2007.

\begin{tabular}{|c|c|c|c|c|c|c|c|c|c|c|c|c|}
\hline \multicolumn{13}{|c|}{$A$-with $k=1$} \\
\hline \multirow[b]{2}{*}{ Regressors } & \multicolumn{4}{|c|}{ Random effects } & \multicolumn{4}{|c|}{ Fixed effects } & \multicolumn{4}{|c|}{ GMM } \\
\hline & $\begin{array}{c}\text { Energy } \\
\text { Use }\end{array}$ & $\mathrm{CO} 2$ & $\mathrm{CH}_{4}$ & $\mathrm{CO}$ & $\begin{array}{c}\text { Energy } \\
\text { Use } \\
\end{array}$ & $\mathrm{CO} 2$ & $\mathrm{CH}_{4}$ & $\mathrm{CO}$ & $\begin{array}{c}\text { Energy } \\
\text { Use } \\
\end{array}$ & $\mathrm{CO} 2$ & $\mathrm{CH}_{4}$ & $\mathrm{CO}$ \\
\hline \multirow[t]{2}{*}{$\ln \left(y_{t-n}\right)$} & 0.9933 & 0.9995 & 0.9997 & 0.9793 & 0.7143 & 0.7497 & 0.7342 & 0.5109 & 0.0976 & 0.6736 & 0.5373 & 0.3847 \\
\hline & {$[0.000]$} & {$[0.000]$} & {$[0.000]$} & {$[0.000]$} & {$[0.000]$} & {$[0.000]$} & {$[0.000]$} & {$[0.000]$} & {$[0.102]$} & {$[0.000]$} & {$[0.000]$} & {$[0.000]$} \\
\hline \multirow[t]{2}{*}{$\ln (s)$} & 0.0209 & 0.0185 & 0.0014 & 0.0136 & 0.0307 & 0.0075 & 0.0147 & 0.0269 & 0.0423 & 0.0069 & 0.0046 & -0.0192 \\
\hline & {$[0.000]$} & {$[0.000]$} & [0.649] & {$[0.007]$} & {$[0.025]$} & {$[0.065]$} & {$[0.005]$} & {$[0.002]$} & {$[0.452]$} & [0.1551] & {$[0.385]$} & {$[0.073]$} \\
\hline \multirow[t]{2}{*}{$\ln (n+d+g)$} & -0.0630 & -0.0789 & 0.0120 & -0.0976 & -0.0536 & -0.0711 & 0.0132 & -0.6972 & -0.0375 & -0.0591 & 0.0025 & -0.0762 \\
\hline & {$[0.000]$} & {$[0.000]$} & {$[0.020]$} & {$[0.000]$} & {$[0.000]$} & {$[0.000]$} & {$[0.016]$} & {$[0.000]$} & {$[0.000]$} & {$[0.000]$} & {$[0.654]$} & {$[0.000]$} \\
\hline Temporal dummy & Yes & Yes & Yes & Yes & Yes & Yes & Yes & Yes & No & No & No & No \\
\hline Convergence & 0.0029 & 0.0002 & 0.0001 & 0.0091 & 0.1461 & 0.1251 & 0.1342 & 0.2916 & - & 0.1716 & 0.2698 & 0.4149 \\
\hline Time (years) & 236.35 & 346.83 & 531.30 & 76.45 & 4.74 & 5.54 & 5.17 & 2.38 & - & 4.04 & 2.57 & 1.67 \\
\hline \multicolumn{13}{|c|}{$B-$ with $k=4$} \\
\hline \multirow[t]{2}{*}{$\ln \left(y_{t-n}\right)$} & 0.9384 & 0.9334 & 0.9672 & 0.8684 & 0.0179 & 0.1288 & 0.1591 & -0.2170 & -0.1618 & -0.0004 & 0.0159 & -0.0168 \\
\hline & {$[0.000]$} & {$[0.000]$} & {$[0.000]$} & {$[0.000]$} & {$[0.672]$} & {$[0.000]$} & {$[0.000]$} & {$[0.000]$} & {$[0.278]$} & [0.976] & {$[0.358]$} & {$[0.000]$} \\
\hline \multirow[t]{2}{*}{$\ln (s)$} & 0.0476 & -0.0431 & 0.0209 & -0.0193 & 0.0304 & 0.0013 & 0.0379 & 0.0423 & 0.0026 & 0.0035 & 0.0057 & -0.0370 \\
\hline & {$[0.014]$} & [0.959] & {$[0.014]$} & [0.179] & {$[0.134]$} & [0.869] & {$[0.000]$} & {$[0.006]$} & {$[0.718]$} & {$[0.576]$} & [0.389] & {$[0.018]$} \\
\hline \multirow[t]{2}{*}{$\ln (n+d+g)$} & -0.0569 & -0.0608 & 0.0163 & -0.0690 & -0.2217 & -0.0423 & 0.0078 & -0.0456 & -0.0433 & -0.0677 & 0.0050 & -0.5462 \\
\hline & {$[0.000]$} & {$[0.000]$} & {$[0.077]$} & {$[0.000]$} & [0.039] & {$[0.000]$} & {$[0.237]$} & {$[0.000]$} & {$[0.000]$} & {$[0.000]$} & {$[0.464]$} & {$[0.000]$} \\
\hline Temporal dummy & Yes & Yes & Yes & Yes & Yes & Yes & Yes & Yes & No & No & No & No \\
\hline Convergence & 0.0092 & 0.0100 & 0.0048 & 0.0204 & - & 0.2967 & 0.2662 & - & - & - & - & - \\
\hline Time (years) & 75.35 & 69.47 & 143.57 & 33.93 & - & 2.34 & 2.60 & - & - & - & - & - \\
\hline
\end{tabular}

The convergence evidence with a lag of four years is not strong. First, it fails to estimate the correct signals for the controls, $s$, and $n+d+g$, for some pollutants. This pattern also appears in other samples. Furthermore, 7 of the 12 models reported statically significant convergence rates. It is important to note that even the estimator RE reported higher rates, 11 to 47 years convergence for all pollutants. The FE estimates report high rates of $\mathrm{CO} 2$ and $\mathrm{CH} 4$ emissions, resulting in less than three years for convergence. The GMM did not report statistically significant rates for any of the GHG. Therefore, for the full sample we found moderate evidence of convergence in per capita emissions of $\mathrm{CO} 2$, and $\mathrm{CH} 4$ because $\mathrm{FE}$ reported parameters that were statistically significant in both time-intervals.

The same result for the controls was observed in Sample-A which includes agriculture and food industrial sectors (Table 2). GMM and FE models estimated similar parameters showing a tendency of convergence with one lag. With a time interval of four years, the emissions per energy use and carbon monoxide emissions presented weak evidence of convergence (statistically 
significant only with RE), while evidence for $\mathrm{CO} 2$ emissions was moderate (reported by FE). We found strong evidence of CH4 emissions among sectors of Sample-A, less than two (with $k=1$ ) and less than two years (with $k=4$ ) as GMM and FE shown statistically significant convergence rates.

Table 2 - Results for sample-A 1996 - 2007.

\begin{tabular}{|c|c|c|c|c|c|c|c|c|c|c|c|c|}
\hline \multicolumn{13}{|c|}{$A-$ with $k=1$} \\
\hline \multirow[b]{2}{*}{ Regressors } & \multicolumn{4}{|c|}{ Random effects } & \multicolumn{4}{|c|}{ Fixed effects } & \multicolumn{4}{|c|}{ GMM } \\
\hline & $\begin{array}{c}\text { Energy } \\
\text { Use }\end{array}$ & $\mathrm{CO} 2$ & $\mathrm{CH}_{4}$ & $\mathrm{CO}$ & $\begin{array}{c}\text { Energy } \\
\text { Use }\end{array}$ & $\mathrm{CO2}$ & $\mathrm{CH}_{4}$ & $\mathrm{CO}$ & $\begin{array}{c}\text { Energy } \\
\text { Use }\end{array}$ & $\mathrm{CO2}$ & $\mathrm{CH}_{4}$ & $\mathrm{CO}$ \\
\hline \multirow[t]{2}{*}{$\ln \left(y_{t-n}\right)$} & 0.9873 & 0.9828 & 1.0011 & 0.9720 & 0.4548 & 0.7901 & 0.7728 & 0.4449 & 0.1503 & 0.6462 & 0.5078 & 0.3251 \\
\hline & [0.000] & [0.000] & {$[0.000]$} & [0.000] & {$[0.004]$} & [0.000] & [0.000] & {$[0.000]$} & [0.014] & [0.000] & [0.005] & {$[0.000]$} \\
\hline \multirow[t]{2}{*}{$\ln (s)$} & 0.0192 & 0.0048 & 0.1370 & -0.0073 & 0.0171 & 0.0178 & 0.0038 & 0.0032 & 0.0316 & 0.0379 & -0.0116 & -0.1981 \\
\hline & {$[0.057]$} & [0.830] & {$[0.158]$} & [0.804] & {$[0.553]$} & [0.517] & {$[0.771]$} & [0.959] & {$[0.196]$} & {$[0.411]$} & {$[0.581]$} & {$[0.134]$} \\
\hline \multirow[t]{2}{*}{$\ln (n+d+g)$} & -0.0518 & -0.0613 & 0.0098 & -0.0815 & -0.0516 & 0.6243 & 0.0107 & -0.0741 & -0.0424 & -0.0561 & 0.0053 & -0.0474 \\
\hline & {$[0.000]$} & {$[0.000]$} & {$[0.0876]$} & {$[0.008]$} & {$[0.000]$} & [0.007] & [0.0973] & {$[0.018]$} & {$[0.000]$} & {$[0.000]$} & {$[0.305]$} & {$[0.138]$} \\
\hline Temporal dummy & Yes & Yes & Yes & Yes & Yes & Yes & Yes & Yes & No & No & No & No \\
\hline Convergence & 0.0055 & 0.0075 & - & 0.0123 & 0.3422 & 0.1023 & 0.1119 & 0.3517 & 0.8230 & 0.1896 & 0.2943 & 0.4880 \\
\hline Time (years) & 125.17 & 92.15 & - & 56.20 & 2.03 & 6.77 & 6.19 & 1.97 & 0.84 & 3.66 & 2.35 & 1.42 \\
\hline \multicolumn{13}{|c|}{$B-$ with $k=4$} \\
\hline \multirow[t]{2}{*}{$\ln \left(y_{t-n}\right)$} & 0.8991 & 0.8482 & 0.9975 & 0.8981 & -0.0569 & 0.2453 & 0.3873 & -0.4058 & -0.0249 & 0.0637 & 0.0336 & -0.5481 \\
\hline & [0.000] & [0.000] & [0.000] & [0.000] & [0.367] & [0.031] & [0.000] & {$[0.0001]$} & [0.474] & [0.2335] & [0.000] & [0.000] \\
\hline \multirow[t]{2}{*}{$\ln (s)$} & 0.0622 & 0.0376 & 0.0373 & -0.0317 & -0.0037 & 0.0798 & 0.0372 & -0.0075 & 0.0070 & 0.4458 & -0.0056 & -0.3568 \\
\hline & {$[0.162]$} & {$[0.472]$} & [0.308] & [0.798] & [0.942] & [0.145] & {$[0.1881]$} & {$[0 ; 960]$} & {$[0.780]$} & {$[0.446]$} & {$[0.880]$} & [0.012] \\
\hline \multirow[t]{2}{*}{$\ln (n+d+g)$} & -0.0529 & -0.4067 & 0.0036 & 0.0053 & -0.0360 & -0.0388 & 0.0087 & -0.2793 & 0.3437 & -0.0547 & 0.0037 & -0.0116 \\
\hline & {$[0.000]$} & [0.023] & [0.7772] & [0.910] & {$[0.000]$} & {$[0.000]$} & {$[0.221]$} & {$[0.533]$} & {$[0.000]$} & {$[0.000]$} & [0.385] & [0.629] \\
\hline Temporal dummy & Yes & Yes & Yes & Yes & Yes & Yes & Yes & Yes & No & No & No & No \\
\hline Convergence & 0.0154 & 0.0238 & 0.0004 & 0.0156 & - & 0.2034 & 0.1373 & - & - & - & 0.4912 & - \\
\hline Time (years) & 45.03 & 29.09 & 1912.84 & 44.57 & - & 3.41 & 5.05 & - & - & - & 1.41 & - \\
\hline
\end{tabular}

*P-values between brackets. *Convergence rate was estimated only for significant parameters.

Methane, $\mathrm{CH} 4$, is present in most of the nitrogen fertilizers used in agriculture. Since the increased use of GM seeds in the 1990s in particular, agricultural techniques have been standardized around the world, and now peasants and farmers have to follow a rigorous process of fertilizer application (and cultivation, in general) recommended by the producers of the seeds. This might help explain this strong evidence of convergence in $\mathrm{CH} 4$ in the agricultural sector.

Table 3 shows the results for Sample-B, the Mining industry. The number of times that the signal of each control-variable was predicted incorrectly increased, whereas the statistical significance decreases. The RE model incorrectly predicts convergence in the emission of CO2 and CH4 with a one year lag, but reported significant estimates with $k=4$. Regarding FE, it found evidence of convergence for GHG with $k=1$, but only for the emissions for energy use and $\mathrm{CH} 4$ with a time interval of four years. Note that this macro-sector includes the largest global pollutants: the mineral extraction activities, wood, and the petrochemical industry. Even so, a high rate of 
convergence in emissions relevant for energy use was found in the FE model, from 7 to less than 1 year, depending on the time horizon. However, as these are the major pollutants, their rates are even higher in an eventual steady-state.

Table 3 - Results for sample-B 1996 - 2007.

\begin{tabular}{|c|c|c|c|c|c|c|c|c|c|c|c|c|}
\hline \multicolumn{13}{|c|}{$A-$ with $k=1$} \\
\hline \multirow[b]{2}{*}{ Regressors } & \multicolumn{4}{|c|}{ Random effects } & \multicolumn{4}{|c|}{ Fixed effects } & \multicolumn{4}{|c|}{ GMM } \\
\hline & $\begin{array}{c}\text { Energy } \\
\text { Use } \\
\end{array}$ & $\mathrm{CO} 2$ & $\mathrm{CH}_{4}$ & $\mathrm{CO}$ & $\begin{array}{c}\text { Energy } \\
\text { Use } \\
\end{array}$ & $\mathrm{CO} 2$ & $\mathrm{CH}_{4}$ & $\mathrm{CO}$ & $\begin{array}{c}\text { Energy } \\
\text { Use } \\
\end{array}$ & $\mathrm{CO} 2$ & $\mathrm{CH}_{4}$ & $\mathrm{CO}$ \\
\hline \multirow[t]{2}{*}{$\ln \left(y_{t-n}\right)$} & 0.9915 & 1.0003 & 1.0001 & 0.9716 & 0.7880 & 0.7819 & 0.7398 & 0.4937 & 0.0229 & 0.7022 & 0.3220 & 0.2823 \\
\hline & {$[0.000]$} & {$[0.000]$} & {$[0.000]$} & {$[0.000]$} & {$[0.000]$} & {$[0.000]$} & {$[0.000]$} & {$[0.000]$} & {$[0.648]$} & {$[0.044]$} & {$[0.001]$} & [0.000] \\
\hline \multirow[t]{2}{*}{$\ln (s)$} & 0.0327 & 0.0242 & 0.0094 & 0.0264 & 0.0209 & 0.1056 & 0.0185 & 0.0413 & 0.0128 & -0.0283 & -0.0039 & -0.0544 \\
\hline & {$[0.06]$} & {$[0.0584]$} & $\begin{array}{c}{[0.205]} \\
-\end{array}$ & [0.109] & [0.206] & [0.289] & $\begin{array}{c}{[0.125]} \\
-\end{array}$ & {$[0.101]$} & [0.449] & {$[0.847]$} & {$[0.768]$} & [0.033] \\
\hline \multirow[t]{2}{*}{$\ln (n+d+g)$} & -0.0603 & -0.0920 & 0.0030 & -0.1030 & -0.0550 & -0.0794 & 0.0088 & -0.0618 & -0.0321 & -0.0596 & -0.0083 & -0.0510 \\
\hline & {$[0.000]$} & {$[0.000]$} & [0.832] & {$[0.000]$} & {$[0.000]$} & {$[0.000]$} & {$[0.535]$} & {$[0.000]$} & {$[0.000]$} & {$[0.000]$} & [0.387] & [0.001] \\
\hline Temporal dummy & Yes & Yes & Yes & Yes & Yes & Yes & Yes & Yes & No & No & No & No \\
\hline Convergence & 0.0037 & - & - & 0.0125 & 0.1035 & 0.1069 & 0.1309 & 0.3065 & - & 0.1536 & 0.4922 & 0.5492 \\
\hline Time (years) & 186.75 & - & - & 55.48 & 6.70 & 6.49 & 5.29 & 2.26 & - & 4.51 & 1.41 & 1.26 \\
\hline \multicolumn{13}{|c|}{$B$ - with $k=4$} \\
\hline \multirow[t]{2}{*}{$\ln \left(y_{t-n}\right)$} & 0.8282 & 0.9440 & 0.9783 & 0.8225 & 0.1578 & 0.0603 & 0.0864 & -0.2993 & -0.0068 & -0.0489 & -0.0252 & -0.3015 \\
\hline & {$[0.000]$} & {$[0.000]$} & {$[0.000]$} & {$[0.000]$} & {$[0.008]$} & {$[0.218]$} & {$[0.382]$} & {$[0.000]$} & 0.7950 & {$[0.258]$} & [0.0731] & [0.000] \\
\hline \multirow[t]{2}{*}{$\ln (s)$} & 0.0155 & -0.0093 & 0.0459 & 0.0061 & -0.0674 & -0.0139 & 0.0331 & 0.0724 & -0.0087 & -0.0097 & 0.0010 & -0.1191 \\
\hline & [0.615] & {$[0.716]$} & [0.019] & [0.905] & {$[0.823]$} & {$[0.469]$} & {$[0.129]$} & {$[0.084]$} & {$[0.694]$} & {$[0.527]$} & {$[.0 .946]$} & [0.002] \\
\hline \multirow[t]{2}{*}{$\ln (n+d+g)$} & -0.0565 & -0.0977 & 0.0168 & -0.0542 & -0.0472 & -0.0671 & 0.0121 & -0.0421 & -0.0327 & -0.0644 & -0.0063 & -0.0380 \\
\hline & {$[0.000]$} & {$[0.000]$} & [0.408] & [0.087] & {$[0.001]$} & {$[0.002]$} & {$[0.358]$} & {$[0.048]$} & {$[0.000]$} & {$[0.000]$} & {$[0.654]$} & [0.048] \\
\hline Temporal dummy & Yes & Yes & Yes & Yes & Yes & Yes & Yes & Yes & No & No & No & No \\
\hline Convergence & 0.0273 & 0.0083 & 0.0032 & 0.0283 & 0.2673 & - & 0.3545 & - & - & - & - & - \\
\hline Time (years) & 25.40 & 83.10 & 218.25 & 24.50 & 2.59 & - & 1.96 & - & - & - & - & - \\
\hline
\end{tabular}

There is no evidence of convergence in GHG emission in the GMM model with $k=4$, only with $k=1$. In this case, the high value of convergence rates is noteworthy, following previous results. It is also interesting to note the increase in the convergence rate of emissions for energy use in the RE and FE models, which changed from 0.0037 to 0.0819 , and 0.1035 to 0.8019 , respectively.

The estimated behavior follows a different pattern in Sample-C, the Manufacturing of nondurable goods (Table 4). With RE, and $k=4$, the convergence rate changes from virtually null values to similar results estimated by FE, primarily in the sectorial emissions for energy use, and $\mathrm{CO} 2$ emissions, in general. However, in none of the gases we found strong evidence of convergence, only moderate in the emission of $\mathrm{CO} 2$ and $\mathrm{CH} 4$ (reported only by the FE model). In both cases, the time for convergence is less than 6 and 12, with $k=1$, and less than 4 and 7 with $k=4$. 
Table 4 - Results for sample-C 1996 - 2007.

\begin{tabular}{|c|c|c|c|c|c|c|c|c|c|c|c|c|}
\hline \multicolumn{13}{|c|}{$A-$ with $k=1$} \\
\hline \multirow[b]{2}{*}{ Regressors } & \multicolumn{4}{|c|}{ Random effects } & \multicolumn{4}{|c|}{ Fixed effects } & \multicolumn{4}{|c|}{ GMM } \\
\hline & $\begin{array}{c}\text { Energy } \\
\text { Use } \\
\end{array}$ & $\mathrm{CO} 2$ & $\mathrm{CH}_{4}$ & $\mathrm{CO}$ & $\begin{array}{c}\text { Energy } \\
\text { Use }\end{array}$ & $\mathrm{CO} 2$ & $\mathbf{C H}_{4}$ & $\mathrm{CO}$ & $\begin{array}{c}\text { Energy } \\
\text { Use }\end{array}$ & $\mathrm{CO} 2$ & $\mathbf{C H}_{4}$ & $\mathrm{CO}$ \\
\hline \multirow[t]{2}{*}{$\ln \left(y_{t-n}\right)$} & 0.9950 & 0.9950 & 1.0053 & 0.9770 & 0.6042 & 0.7667 & 0.8799 & 0.5442 & 0.0910 & 0.4742 & 0.4898 & 0.2855 \\
\hline & {$[0.000]$} & {$[0.000]$} & {$[0.000]$} & {$[0.000]$} & {$[0.000]$} & {$[0.000]$} & {$[0.000]$} & {$[0.000]$} & [0.339] & {$[0.008]$} & {$[0.000]$} & {$[0.000]$} \\
\hline \multirow[t]{2}{*}{$\ln (s)$} & 0.0268 & 0.0099 & 0.0024 & 0.0074 & 0.0028 & 0.0040 & -0.0051 & -0.0088 & -0.0064 & -0.0025 & -0.0147 & -0.0144 \\
\hline & {$[0.006]$} & {$[0.260]$} & [0.819] & {$[0.627]$} & {$[0.796]$} & {$[0.737]$} & [0.686] & {$[0.631]$} & {$[0.373]$} & [0.8122] & {$[0.292]$} & {$[0.424]$} \\
\hline \multirow[t]{2}{*}{$\ln (n+d+g)$} & -0.0419 & -0.0391 & 0.0464 & -0.0761 & -0.0358 & -0.0449 & 0.0392 & -0.0714 & -0.0291 & -0.0345 & 0.0231 & -0.0591 \\
\hline & {$[0.000]$} & {$[0.000]$} & {$[0.000]$} & {$[0.000]$} & {$[0.000]$} & {$[0.000]$} & {$[0.000]$} & {$[0.001]$} & {$[0.001]$} & {$[0.000]$} & {$[0.078]$} & {$[0.001]$} \\
\hline Temporal dummy & Yes & Yes & Yes & Yes & Yes & Yes & Yes & Yes & No & No & No & No \\
\hline Convergence & 0.0022 & 0.0022 & - & 0.0101 & 0.2188 & 0.1154 & 0.0556 & 0.2642 & - & 0.3240 & 0.3100 & 0.5444 \\
\hline Time (years) & 315.87 & 317.77 & - & 68.59 & 3.17 & 6.01 & 12.47 & 2.62 & - & 2.14 & 2.24 & 1.27 \\
\hline \multicolumn{13}{|c|}{$B-$ with $k=4$} \\
\hline \multirow[t]{2}{*}{$\ln \left(y_{t-n}\right)$} & 0.8002 & 0.8532 & 1.0001 & 0.8173 & 0.0089 & 0.2145 & 0.3612 & -0.2675 & 0.0635 & -0.0209 & 0.0171 & -0.3572 \\
\hline & {$[0.000]$} & {$[0.000]$} & {$[0.000]$} & {$[0.000]$} & {$[0.902]$} & {$[0.003]$} & {$[0.000]$} & {$[0.005]$} & {$[0.224]$} & {$[0.657]$} & {$[0.684]$} & {$[0.000]$} \\
\hline \multirow[t]{2}{*}{$\ln (s)$} & 0.0251 & 0.0098 & 0.0308 & 0.0049 & 0.0032 & -0.0008 & 0.0473 & 0.0221 & -0.0099 & 0.0005 & -0.0065 & -0.0302 \\
\hline & {$[0.226]$} & {$[0.612]$} & {$[0.237]$} & {$[0.885]$} & {$[0.825]$} & {$[0.962]$} & {$[0.093]$} & {$[0.476]$} & {$[0.216]$} & {$[0.967]$} & {$[0.782]$} & [0.123] \\
\hline \multirow[t]{2}{*}{$\ln (n+d+g)$} & -0.0282 & -0.0675 & 0.0532 & -0.0224 & -0.0042 & -0.0375 & 0.0920 & -0.0335 & -0.0238 & -0.0350 & 0.0121 & 0.0051 \\
\hline & {$[0.082]$} & {$[0.000]$} & [0.019] & {$[0.517]$} & {$[0.773]$} & {$[0.006]$} & [0.613] & {$[0.240]$} & {$[0.086]$} & {$[0.001]$} & {$[0.428]$} & {$[0.851]$} \\
\hline Temporal dummy & Yes & Yes & Yes & Yes & Yes & Yes & Yes & Yes & No & No & No & No \\
\hline Convergence & 0.0323 & 0.0230 & - & 0.0292 & - & 0.2229 & 0.1474 & - & - & - & - & - \\
\hline Time (years) & 21.48 & 30.17 & - & 23.73 & - & 3.11 & 4.70 & - & - & - & - & - \\
\hline
\end{tabular}

*P-values between brackets. *Convergence rate was estimated only for significant parameters.

Regarding GMM, there is only statically significant evidence of convergence with a time lag of 1 year. It is also appropriate to note that in this case, the parameters associated with the savings rate were biased, with the opposite sign, in all greenhouse gases. In both cases, however, the estimated time for convergence is less than 3 years.

A similar biased pattern occurs in the GMM estimate of the Sample-D, the Manufacturing of "durable goods" industry (Table 5), and only CH4 and CO parameters are statistically significant with $k=1$. FE and RE estimations shown statically significant convergence rates for all GHG. As expected RE found low rates of convergence, while the control of the specific characteristics of sectors increases evidence of convergence. However, with $k=4$, we found moderate evidence of convergence in $\mathrm{CH} 4$ per capita emissions, less than 1 year.

In both industrial sectors (sample $\mathrm{C}$, and $\mathrm{D}$ ), the percentage of times that models predicts the parameters of savings, population, technical change, and depreciation rates incorrectly increased considerably, which may suggest that our Solow-type specification is not the best to model GHG emissions in such sectors. However, this pattern is now present in RE and FE models. 
Table 5 - Results for sample-D 1996 - 2007.

\begin{tabular}{|c|c|c|c|c|c|c|c|c|c|c|c|c|}
\hline \multicolumn{13}{|c|}{$A-$ with $k=1$} \\
\hline \multirow[b]{2}{*}{ Regressors } & \multicolumn{4}{|c|}{ Random effects } & \multicolumn{4}{|c|}{ Fixed effects } & \multicolumn{4}{|c|}{ GMM } \\
\hline & $\begin{array}{c}\text { Energy } \\
\text { Use }\end{array}$ & $\mathrm{CO} 2$ & $\mathrm{CH}_{4}$ & $\mathrm{CO}$ & $\begin{array}{c}\text { Energy } \\
\text { Use }\end{array}$ & $\mathrm{CO} 2$ & $\mathrm{CH}_{4}$ & $\mathrm{CO}$ & $\begin{array}{c}\text { Energy } \\
\text { Use }\end{array}$ & $\mathrm{CO} 2$ & $\mathrm{CH}_{4}$ & $\mathrm{CO}$ \\
\hline \multirow[t]{2}{*}{$\ln \left(y_{t-n}\right)$} & 0.9944 & 0.9948 & 0.9971 & 0.9791 & 0.5594 & 0.6527 & 0.6809 & 0.5021 & 0.0832 & 0.1904 & 0.3684 & 0.3293 \\
\hline & {$[0.000]$} & {$[0.000]$} & {$[0.000]$} & {$[0.000]$} & {$[0.000]$} & {$[0.000]$} & [0.000] & {$[0.000]$} & {$[0.148]$} & {$[0.360]$} & [0.001] & [0.000] \\
\hline \multirow[t]{2}{*}{$\ln (s)$} & 0.0014 & 0.0066 & -0.0116 & -0.0179 & 0.0059 & 0.0966 & 0.0249 & 0.0732 & -0.0159 & -0.0087 & 0.0143 & -0.1026 \\
\hline & [0.867] & {$[0.526]$} & [0.436] & [0.439] & [0.642] & {$[0.575]$} & [0.281] & [0.049] & [0.427] & [0.529] & {$[0.418]$} & {$[0.070]$} \\
\hline \multirow[t]{2}{*}{$\ln (n+d+g)$} & -0.0597 & -0.0734 & 0.0197 & -0.0751 & -0.0542 & -0.0636 & 0.0241 & -0.0544 & -0.0223 & -0.0378 & 0.0091 & -0.0559 \\
\hline & {$[0.000]$} & {$[0.000]$} & {$[0.060]$} & {$[0.000]$} & {$[0.000]$} & {$[0.000]$} & {$[0.015]$} & {$[0.003]$} & {$[0.003]$} & {$[0.000]$} & {$[0.285]$} & {$[0.004]$} \\
\hline Temporal dummy & Yes & Yes & Yes & Yes & Yes & Yes & Yes & Yes & No & No & No & No \\
\hline Convergence & 0.0024 & 0.0023 & 0.0013 & 0.0092 & 0.2523 & 0.1853 & 0.1669 & 0.2992 & - & - & 0.4337 & 0.4824 \\
\hline Time (years) & 284.97 & 303.21 & 540.23 & 75.60 & 2.75 & 3.74 & 4.15 & 2.32 & - & - & 1.60 & 1.44 \\
\hline \multicolumn{13}{|c|}{$B-$ with $k=4$} \\
\hline \multirow[t]{2}{*}{$\ln \left(y_{t-n}\right)$} & 0.9394 & 0.9219 & 0.9254 & 0.8606 & 0.0437 & 0.0850 & 0.1930 & -0.1169 & 0.0061 & -0.0584 & -0.0047 & -0.1525 \\
\hline & {$[0.000]$} & {$[0.000]$} & {$[0.000]$} & {$[0.000]$} & {$[0.429]$} & {$[0.232]$} & {$[0.011]$} & {$[0.160]$} & [0.794] & 0.0770 & {$[0.865]$} & {$[0.012]$} \\
\hline \multirow[t]{2}{*}{$\ln (s)$} & -0.0319 & -0.0294 & -0.0012 & -0.0287 & -0.0267 & -0.0169 & 0.0659 & 0.0998 & -0.0276 & -0.0144 & 0.0158 & -0.1386 \\
\hline & {$[0.280]$} & {$[0.361]$} & {$[0.975]$} & {$[0.548]$} & {$[0.2760]$} & {$[0.5553]$} & {$[0.087]$} & {$[0.098]$} & [0.244] & {$[0.354]$} & {$[0.438]$} & [0.052] \\
\hline \multirow[t]{2}{*}{$\ln (n+d+g)$} & -0.0706 & -0.0560 & 0.0151 & -0.0801 & -0.0401 & -0.0443 & 0.0122 & -0.0586 & -0.0323 & -0.0412 & 0.0013 & -0.0571 \\
\hline & {$[0.000]$} & {$[0.000]$} & [0.477] & [0.001] & {$[0.000]$} & {$[0.000]$} & [0.262] & {$[0.005]$} & {$[0.005]$} & {$[0.000]$} & {$[0.838]$} & [0.014] \\
\hline Temporal dummy & Yes & Yes & Yes & Yes & Yes & Yes & Yes & Yes & No & No & No & No \\
\hline Convergence & 0.0091 & 0.0118 & 0.0112 & 0.0217 & - & - & 0.2382 & - & - & - & - & - \\
\hline Time (years) & 76.54 & 58.87 & 61.78 & 31.89 & - & - & 2.91 & - & - & - & - & - \\
\hline
\end{tabular}

*P-values between brackets. *Convergence rate was estimated only for significant parameters.

Regarding Services sector, Sample-E, the parameters of the neoclassical model were correctly estimated in both time intervals. The GLS estimator of RE tends to show low convergence rates with $k=1$, increasing with the rise in the time interval, which in turn, resulted in a marked decrease in the time of convergence for all pollutants. Note that the time for convergence varies from less than 25 to 12 years in the RE model.

GMM and FE models shown high rates of convergence when considering the interval of one year, approaching steady-state in about 2-7 years for each gas. With a four-year lag, only the emission of $\mathrm{CO} 2$ and $\mathrm{CH} 4$ are statistically significant in the FE model, and CH4 in GMM. It is surprising that in both cases, the speed of convergence is less than one year, for the period immediately prior to the global economic crisis of 2008. 
Table 6 - Results for sample-E 1996 - 2007.

\begin{tabular}{|c|c|c|c|c|c|c|c|c|c|c|c|c|}
\hline \multicolumn{13}{|c|}{$A-$ with $k=1$} \\
\hline & \multicolumn{4}{|c|}{ Random effects } & \multicolumn{4}{|c|}{ Fixed effects } & \multicolumn{4}{|c|}{ GMM } \\
\hline Regressors & $\begin{array}{c}\text { Energy } \\
\text { Use }\end{array}$ & $\mathrm{CO} 2$ & $\mathrm{CH}_{4}$ & $\mathrm{CO}$ & $\begin{array}{c}\text { Energy } \\
\text { Use } \\
\end{array}$ & $\mathrm{CO} 2$ & $\mathrm{CH}_{4}$ & $\mathrm{CO}$ & $\begin{array}{c}\text { Energy } \\
\text { Use } \\
\end{array}$ & $\mathrm{CO} 2$ & $\mathrm{CH}_{4}$ & $\mathrm{CO}$ \\
\hline \multirow{2}{*}{$\ln \left(y_{t-n}\right)$} & 0.9900 & 0.9937 & 0.9981 & 0.9786 & 0.7516 & 0.7869 & 0.7415 & 0.5090 & 0.3383 & 0.6769 & 0.5155 & 0.4856 \\
\hline & {$[0.000]$} & {$[0.000]$} & {$[0.000]$} & {$[0.000]$} & {$[0.000]$} & {$[0.000]$} & {$[0.000]$} & {$[0.000]$} & {$[0.006]$} & {$[0.000]$} & {$[0.000]$} & {$[0.000]$} \\
\hline \multirow[t]{2}{*}{$\ln (s)$} & 0.0322 & 0.0195 & -0.0016 & 0.0186 & 0.0437 & 0.0058 & 0.0109 & 0.0273 & 0.0084 & 0.0054 & 0.0047 & -0.0054 \\
\hline & {$[0.000]$} & {$[0.000]$} & {$[0.614]$} & {$[0.002]$} & {$[0.055]$} & {$[0.224]$} & {$[0.080]$} & {$[0.010]$} & [0.204] & {$[0.273]$} & {$[0.377]$} & [0.616] \\
\hline \multirow[t]{2}{*}{$\ln (n+d+g)$} & -0.0765 & -0.0913 & 0.0054 & -0.0113 & -0.0584 & -0.0849 & 0.0112 & -0.0872 & -0.0570 & -0.0752 & 0.0024 & -0.1174 \\
\hline & {$[0.000]$} & {$[0.000]$} & {$[0.528]$} & {$[0.000]$} & {$[0.001]$} & {$[0.000]$} & [0.219] & {$[0.000]$} & {$[0.000]$} & {$[0.000]$} & {$[0.800]$} & {$[0.000]$} \\
\hline Temporal dummy & Yes & Yes & Yes & Yes & Yes & Yes & Yes & Yes & No & No & No & No \\
\hline Convergence & 0.0044 & 0.0027 & 0.0008 & 0.0094 & 0.1240 & 0.1041 & 0.1299 & 0.2933 & 0.4707 & 0.1695 & 0.2878 & 0.3137 \\
\hline Time (years) & 158.14 & 252.14 & 817.68 & 73.68 & 5.59 & 6.66 & 5.34 & 2.36 & 1.47 & 4.09 & 2.41 & 2.21 \\
\hline \multicolumn{13}{|c|}{$B$ - with $k=4$} \\
\hline \multirow[t]{2}{*}{$\ln \left(y_{t-n}\right)$} & 0.9386 & 0.9206 & 0.9550 & 0.8768 & -0.0509 & 0.1708 & 0.1348 & -0.2444 & -0.0372 & 0.0072 & 0.0509 & -0.0942 \\
\hline & {$[0.000]$} & {$[0.000]$} & {$[0.000]$} & {$[0.000]$} & {$[0.430]$} & {$[0.002]$} & {$[0.002]$} & {$[0.000]$} & {$[0.013]$} & {$[0.743]$} & {$[0.023]$} & [0.034] \\
\hline \multirow[t]{2}{*}{$\ln (s)$} & 0.0365 & 0.0011 & 0.0046 & -0.0182 & 0.0578 & 0.0055 & 0.0203 & 0.0294 & 0.0049 & 0.0015 & 0.0062 & -0.0125 \\
\hline & {$[0.059]$} & [0.991] & {$[0.632]$} & {$[0.296]$} & {$[0.095]$} & {$[0.574]$} & {$[0.046]$} & {$[0.097]$} & {$[0.519]$} & {$[0.818]$} & {$[0.340]$} & {$[0.421]$} \\
\hline \multirow[t]{2}{*}{$\ln (n+d+g)$} & -0.0522 & -0.0333 & 0.0262 & -0.0764 & 0.0077 & -0.0221 & 0.0127 & -0.0477 & -0.0510 & -0.0772 & 0.0050 & -0.1188 \\
\hline & {$[0.010]$} & {$[0.061]$} & {$[0.083]$} & {$[0.002]$} & {$[0.781]$} & {$[0.046]$} & {$[0.00]$} & {$[0.010]$} & {$[0.000]$} & {$[0.000]$} & {$[0.573]$} & {$[0.000]$} \\
\hline Temporal dummy & Yes & Yes & Yes & Yes & Yes & Yes & Yes & Yes & No & No & No & No \\
\hline Convergence & 0.0092 & 0.0120 & 0.0067 & 0.0190 & - & 0.2558 & 0.2901 & - & - & - & 0.4310 & - \\
\hline Time (years) & 75.52 & 57.87 & 103.99 & 36.41 & - & 2.71 & 2.39 & - & - & - & 1.61 & - \\
\hline
\end{tabular}

*P-values between brackets. *Convergence rate was estimated only for significant parameters.

We found moderate evidence of convergence in $\mathrm{CO} 2$ emissions in the Services sector (RE and FE models), while for $\mathrm{CH} 4$ the evidence of convergence is strong, as shown in the model estimated using the generalized method of moments of Arellano and Bond (1991). For the emissions relevant for energy use and carbon monoxide the evidence is weak, since RE estimates report low convergence rates.

\section{Conclusions}

This article focused on the empirical estimation of the convergence hypothesis of greenhouse gases emissions, a test of interest to many works in the environmental economics literature. An understanding of the dynamics of major pollutants is critical to the adoption of appropriate policies related to global warming. Many models of computable general equilibrium are used to estimate future trends for climate change and they assume a certain degree of convergence between countries and sectors. If however, per capita emissions are not converging, these models can be seriously incorrect, generating bad environmental policy recommendations. 
In this study we contribute to the literature in three respects. First, possible inconsistencies in the estimation of the convergence hypothesis are controlled using robust estimators for panel data, as the fixed effects and a GMM of Arellano and Bond (1991). This procedure demonstrates that the convergence rate rises significantly compared to conventional estimates, such as POLS or GLS of random effect, the latter used in this work.

We found evidence of convergence for large data samples, for instance in our sample that includes all sectors of WIOD, more than 14553 observations distributed in 39 countries. Unlike in previous literature, this evidence seems to be regardless to the sample size, even when the GLS of random effects is used in the estimate. Finally, we expanded our analysis to other greenhouse gases, not only cross-country data on $\mathrm{CO} 2$ emissions. We use the emissions relevant for energy use major source of global warming, methane emissions, $\mathrm{CH} 4$, and monoxide carbon emissions, $\mathrm{CO}$.

As expected, the result was very heterogeneous across sectors and among pollutants. Robust evidence of convergence in $\mathrm{CH} 4$ emissions was found in Agriculture and Food Industry (Sample-A), and in the Service macro sector (Sample-E) as shown by our three estimators (RE, FE, and GMM). The result is valid in both time-intervals, four and one year, for the lag in the rate of convergence. The fixed effects estimate also suggests convergence in $\mathrm{CH} 4$ emissions in the Mining industry (Sample-B), Manufacturing industry of durable goods (Sample-D), and non-durable goods (Sample-C).

Carbon dioxide emissions performed more moderately because random and fixed effect models only the reported statistically significant estimates in samples E, and C. We also found moderate evidence in the sample that includes all sectors of WIOD. However, emissions for energy use, mostly non-renewable, were found in the samples B and D. For carbon monoxide emissions, we found weak evidence of convergence because only the estimator random effects tends to report statistically significant parameters and low convergence rates. However, given the violation of the strict exogeneity assumption of this estimator, it is more accurate to assert that there was perhaps no evidence of convergence on the use of this pollutant in any sample set estimated.

Furthermore, although this work advances empirical evidence on the hypothesis of convergence in GHG emissions, building a multi-sectorial panel data using the data from WIOD, it must be noted that the conclusions are valid in a small time horizon, 11 years. In particular, the consideration of one lag to test convergence, as adopted in the literature, may be insufficient for a consistent empirical evaluation. Perhaps for this reason, we found high rates of convergence in almost all gases with $n=1$. Such a result, however, tends to be only valid for some pollutants when the time horizon is enlarged, $n=4$. Despite this, we can only say that the evidence in terms of per 
capita convergence was found for some greenhouse gases and are distributed very heterogeneously among sectors.

\section{References}

ALDY, J. E. (2006). Per capita carbon dioxide emissions: convergence or divergence? Environmental and Resource Economics, v. 33, n. 4, p. 533-555. DOI 10.1007/s10640-0056160-x

ARELLANO, M. BOND, S. (1991). Some tests of specification for panel data: Monte Carlo evidence and an application to employment equations. The Review of Economic and Studies, v.58, n.2., p.277.

BROCK, W.; TAYLOR, M. S. (2010). The green Solow model. Journal of Economic Growth, v. 15, n. 2, p. 127-153. DOI: 101007/s10887-010-9051-0

CAMARERO, M.; PICAZO-TADEO, A. J.; TAMARIT, C. (2013). Are the determinants of $\mathrm{CO}_{2}$ emissions converging among OECD countries? Economic Letters, v. 118, n. 1, p. 159-162. DOI:10.1016/j.econlet.2012.10.009

CRIADO, C. O.; GRETHER, J. M. (2011). Convergence in per capita $\mathrm{CO}_{2}$ emissions: a robust distributional approach. Resource and Energy Economics, v. 33, n. 3, p. 637-665. DOI: 10.1016/j.reseneeco.2011.01.003

GREENE, W. H. (2000). Econometric analysis. New Jersey: Prentice Hall.

HERRERIAS, M. J. (2012). $\mathrm{CO}_{2}$ weighted convergence across the EU-25 countries (1920-2007). Applied Energy, v. 92, p. 09-16. DOI:10.1016/j.apenergy.2011.10.034

IPCC (2014). Climate Change 2014: Synthesis Report, book section Contribution of Working Groups I, II and III to the Fifth Assessment Report of the Intergovernmental Panel on Climate Change, page 1141. IPCC, Geneva, Switzerland.

ISLAM, N. (1995). Growth empirics: a panel data approach. The Quarterly Journal of Economics, v. 110, n. 4 , p. $1127-1170$.

JOBERT, T.; KARANFIL, F.; TYKHONENKO, A. (2010). Convergence of per capita carbon dioxide emissions in the EU: legend or reality? Energy Economics, v. 32, n. 6, p. 1364-1373. DOI: 10.1016/j.eneco.2010.03.005

LI, X.; LIN, B. (2013). Global convergence in per capita $\mathrm{CO}_{2}$ emissions. Renewable and Sustainable Energy Reviews, v. 24, p. 357-363. DOI: 10.1016/j.rser.2013.03.048

MANKIW, N. G.; ROMER, D.; WEIL, D. N. (1992). A contribution to the empirics of economic growth. The Quaterly Journal of Economics, v. 107, n. 2, p. 407-437. DOI: 10.2307/2118477

PEASARAM, M. H. (2007). A simple panel unit root test in the presence of cross-section dependence Journal of Applied Econometrics v. 22, p. 265-312. DOI: 10.1002/jae.951

PEN, L. Y.; SÉVI B. (2010). On the non-convergence of energy intensities: Evidence from a pairwise econometric approach. Ecological Economics v. 69 p. 641-650. DOI: $10.1016 /$ j.ecolecon.2009.10.001

ROMERO-ÁVILA, D. (2008). Convergence in carbon dioxide emissions among industrialized countries revisited. Energy Economics, v. 30, n. 5, p. 2265-2282. DOI 10.1016/j.eneco.2007.06.003 
STRAZICICH, M. C.; LIST, J. A. (2003). Are $\mathrm{CO}_{2}$ emission levels converging among industrial countries? Environmental and Resource Economics, v. 24, n. 3, p. 263-271. DOI: 10.1023/A:1022910701857

TIMMER, M. P.; DIETZENBACHER, E,; LOS, B.; STEHRER, R.; de VRIES, G. J. (2015). An illustrated use guide to the World Input-Output Database: The case of global automotive production. Review of International Economics, v.22, n.3, p.575-605. DOI:10.1111/roie.12178

WESTERLUND, J.; BASHER, S. A. (2008). Testing for convergence in carbon dioxide emissions using a century of panel data. Environmental and Resource Economics, v. 40, n. 1, p. 109-120. DOI: 101007/s10640-007-9143-2

WOOLDRIDGE, J. (2002). Econometric analysis of cross section and panel data. MIT Press. 